\title{
A review of the problems encountered by a non-member spouse in accessing their half share of the pension interest during divorce in South Africa
}

\author{
Mothokoa Mamashela \\ LLM LLM \\ Honorary Research Fellow, University of KwaZulu-Natal
}

\begin{abstract}
OPSOMMING
'n Oorsig van die problem ervaar deur nie-lid eggenote in die verkryging van toegang to hul helfte van pensioenbelang deur die loop van egskeiding in
\end{abstract}

Suid-Afrika

Die deel van 'n gedeelde pensionbelang deur voormalige (maar geskeide) eggenote in gemeenskap van goedere is die onderwerp van geweldige debat in die regsgemeenskap. Die knelpunt is die betekenis en interpretasie van die wetgewing wat hierdie pensioenbelang in 1989 ingestel het. Het die wetgewing bloot net gedien as 'n kodifikasie van die reg soos op daardie stadium, of het dit nuwe beginsels in die egskeidingsreg ingevoer? Hierdie regsonsekerheid het 'n daadwerklike impak gehad op die lid-eggenoot se pensioenbelang. Die einddoel van hierdie artikel is om te besin oor die debat as agtergrond vir die bespreking van sommige van die probleme ervaar deur nie-lid eggenote in die gebruik van hulle deel van die pensioenbelang na afloop van egskeiding.

\section{Introduction}

The interpretation of sections 7(7)(a) and 7(8) of The Divorce Act, 1979 (the DA) is controversial. Different high court judges, ${ }^{1}$ academic writers and practising attorneys ${ }^{2}$ have given divergent interpretations to the sections thus giving rise to more questions than answers. Pertinent questions to this debate regarding section 7(7)(a) are: What is the definition of the pension interest? Does it form part of the joint estate? Is it an asset in the joint estate? Does the joint estate automatically include

1 Sempapalele $v$ Sempapalele 20012 SA 306 (O); Kgopane $v$ Kgopane Case No 1819/2011; Lamb v Lamb 2002 JDR 0463 (T); ML v JL 2013 ZAFSHC 55; Motsetse v Motsetse 20152 All SA 495 (FB); Maharaj v Maharaj 20022 SA 648 (D\&CLD); Chiloane v Chiloane 2007 ZAGPHC 183 (07/09/07); M v M 2016 ZALMPPHC 2 (17/06/2016);

2 Marumoagae "A non-member spouse's entitlement to the member's pension interest" 2014 PER/PELJ 2488 is an excellent and thorough treatise of issues raised in these and many more judgments 2491-2497; Pienaar "Does a non-member spouse have a claim on pension interest?" 2015 De Rebus 1; Davey "Pension interest and divorce $K v K$ and Another: A Critique" 2013 De Rebus 26. Davey's views are criticised by Petse AJA in Ndaba $v$ Ndaba 20171 SA 342 SCA par 25.

How to cite: Mamashela 'A review of the problems encountered by a non-member spouse in accessing their half share of the pension interest during divorce in South Africa' 2018 De Jure 17-34 http://dx.doi.org/10.17159/2225-7160/2018/v51n1a2 
the pension interest? What is the entitlement of the non-member spouse? Does failure to plead and pray for the division of the pension interest in the divorce papers prevent a former non-member spouse from claiming a portion of the pension benefits accorded to the member? ${ }^{3}$ With regard to section 7(8), the questions that the courts have had to answer are: Is the non-member spouse barred in perpetuity to share the member's pension interest where the court that granted the divorce fails to make the section 7(8) order? Can a court that did not grant the divorce subsequently make a section 7(8) order?

The non-member spouse usually bears the brunt of this legal uncertainty when they access their share of the pension interest. Retirement funds present administrative hurdles and technical issues when they are supposed to honour court orders in terms of section 7(8) of the DA. ${ }^{4}$ The focus of this article is to identify and discuss some problems/hurdles confronted by a non-member spouse in accessing their share of the pension interest. These are: the protection of a member's rights by retirement funds/administrators; failure of a member spouse to inform a non-member spouse that they belong to a retirement fund and or to disclose the name thereof; resignation of a member spouse from employment during divorce proceedings; a multiplicity of court processes; rejection of divorce orders and/or settlement agreements by retirement funds; taxation of pension interest payout to a non-member spouse and the percentage of the pension interest the non-member spouse is entitled to on divorce.

The following section highlights, briefly, the raging debate regarding the meaning and interpretation of sections $7(7)(\mathrm{a})$ and $7(8)$ of the DA. I discuss the SCA ruling in Ndaba $v N d a b a^{5}$ and conclude that by answering some and not all the questions raised in the current debate, the SCA has allowed the debated to go on thus missing a golden opportunity to settle the protracted debate once and for all.

\section{Sections 7(7)(a) and 7(8) of the DA}

\section{The debate and selected interpretations}

This section presents the different interpretations of these sections. I point out the confusion caused by some judges and writers in conflating the common law rules governing a marriage in community of property and section 7(7)(a). I discuss Ndaba $v$ Ndaba and point out that the SCA

3 Marumoagae supra $\mathrm{n} 2$ at 2497; Marumoagae "Pension interest - is there a need to plead a claim? 2017 De Rebus 1; Marumoagae "The Law Regarding Pension Interest in South Africa has been settled or has it? With Reference to Ndaba v Ndaba (600/2015) [2016] ZASCA 162" PER/PELJ 14.

4 Mothupi "Some Practical Effects of the Financial Services Laws General Amendment Act 2008 on amending Section 37D(4) of the Pension Funds Act” 2010 SA Merc LJ 216.

5 Marumoagae supra n2. 
failed to settle this interpretative quagmire once and for all. Which means that the debate regarding the unanswered questions will continue to rage on.

As indicated above, since the insertion of section $7(7)(a)$ in the DA, different high courts, some academic writers, attorneys, retirement funds and administrators have interpreted the section differently. ${ }^{6}$ There are two dominant interpretations of the section. The first one, held by some judges, ${ }^{7}$ is that the section changed the erstwhile common law by allowing a non-member spouse to share in the pension interest of a member spouse, which hitherto belonged to them alone and was not shared on divorce. ${ }^{8}$ In other words, it was considered that the section enabled a non-member spouse to enjoy a member spouse's pension interest. The view went on to say that it was only through an order of a court granting a divorce that a non-member spouse could enjoy these benefits. Should a court granting a divorce fail to make a section 7(7)(a) order, a non-member spouse was forever barred from enjoying a member spouse's pension interest. ${ }^{9}$ According to this interpretation, an order in terms of section 7(7)(a) was constitutive of a non-member spouse's rights to share in a member's pension interest. ${ }^{10}$ A constitutive order creates new law. ${ }^{11}$ For instance, in Fourie's case, the Constitutional Court ordered Parliament to change the traditional common law definition of a marriage between a man and a woman to include a marriage between same-sex partners. It was also enlisted to amend $\mathrm{s}$ 30(i) of the Marriage Act 25, 1961 to accommodate same-sex partners and other unconventional relationships.

6 Sempapalele $v$ Sempapalele 20012 SA 306 (O); Kgopane $v$ Kgopane Case No 1819/2011; Lamb v Lamb 2002 JDR 0463 (T); ML v JL 2013 ZAFSHC 55; Motsetse v Motsetse 20152 All SA 495 (FB); Maharaj v Maharaj 20022 SA 648 (D\&CLD); Chiloane v Chiloane 2007 ZAGPHC 183 (07/09/07); M v M 2016 ZALMPPHC 2 (17/06/2016);

$7 \quad$ Sempapalele $v$ Sempapalele supra $\mathrm{n} 1$; Lamb $v$ Lamb supra $\mathrm{n} 1$; Kgopane $v$ Kgopane supra $\mathrm{n} 1$ at 6 par 11; Motsetse $v$ Motsetse supra $\mathrm{n} 1$.

8 N1; Eskom Pension and Provident Fund v Krugel 20126 SA 143 (SCA) 149 CD. The SCA per Maya JA (Brand JA, Lewis JA, Tshiqi JA and Petse AJA concurring) lost a golden opportunity to resolve this interpretation uncertainty; $K v K$ supra $\mathrm{n} 1$.

$9 \quad$ Ndaba $v$ Ndaba supra $\mathrm{n} 2$ par 6 , Kgomo $\mathrm{J}$ in his high court judgment discussed by Petse JA in the majority SCA judgment.

10 Kgopane $v$ Kgopane supra n3 par 14; Eskom Pension and Provident Fund $v$ Krugel n 7144 par E-F; Sempapalele v Sempapalele supra n1; Lamb v Lamb supra n1; BSM v NAM Case No HCA 18/2015; Motsetse v Motsetse supra n1.

11 Minister of Home Affairs v Fourie 2006 (1) SA 524 (CC), a same sex couple could not marry because the common law definition of marriage disallowed them to do so. Parliament was given 12 months to change the traditional common law definition of marriage and make it more inclusive of other types of relationships. 
The second view held by other judges, academic scholars and attorneys, was that an order of a court was not fundamental to a nonmember spouse's rights to share in the pension interest of a member spouse. ${ }^{12}$ According to this interpretation, the absence of a section $7(7)$ (a) court order did not bar a non-member from sharing in a member's pension interest. In the circumstances, the court order merely declares the law as it stands, and does not change anything. ${ }^{13}$ Reiterating the same sentiment, Magid J observed in Maharaj that:

Indeed in this province orders for division of the joint estate of parties married in community of property are consistently refused when divorce orders are granted for the very reason that they are unnecessary. ${ }^{14}$

In other words, the court order is merely declaratory and not constitutive of the non-member's right to share in the pension interest.

At the heart of this debate is the legal nature of a court order under section 7(7)(a) of the DA: is it constitutive or declaratory? If constitutive, it means that should the court hearing the divorce fail to make the order, the non-member spouse is forever barred from claiming their portion of the pension interest. However, if the order is declaratory, it means that failure by the court to make the order does not affect the right of the nonmember spouse to their share of the pension interest. The courts that held that the $\mathrm{s} 7(7)(\mathrm{a})$ order is declaratory based their conclusion on the marital regime of the spouses and not on the interpretation and analysis of section 7(7)(a). Accordingly, they conflated the marital regime and the section which deems the pension interest to be an asset in the member's estate not in the joint estate. None of the courts provide the 'missing link', that is, how is 'his/her estate' converted into 'the joint estate' contemplated in a marriage in community of property. In providing the 'missing link' Marumoagae argues,

Given the language adopted in section 7(7)(a) of the DA, which deems the pension interest to be an asset in the estate of the member spouse, I submit that this section is in effect converting the promise the pension fund made to its member into a realizable value capable of being divided. ${ }^{15}$

In support of his submission, he argues that as the monthly premiums are deducted from the member's salary which in itself is a patrimonial benefit of the marriage, and forms part of the joint estate, the sharing of the pension interest is appropriate and is the right thing to do. If parties are married in community of property, unless there is an identifiable separate estate where one of the parties received non-patrimonial

12 Maharaj v Maharaj supra n1; Chiloane v Chiloane; supra n1; D v D (15402/ 2010) [2013] ZAGPJHC 194 (10/05/2013) Miltz AJ 5 par 14; K v Government Employees' Pension Fund Case No. A3058/2015 2016 ZA 64 (30/03/16) 9 par 13; RN v FK Case No 15438/2015 (23/03/16) par 17.

13 Maharaj $v$ Maharaj supra $n 2$ at 652; Ndaba $v$ Ndaba supra n4 par 26; Peters $v$ Peters 2008 ZAWCHC 309 2/12/2008; Kotze v Kotze 2013 JOL 30037; Mv M supra n2.

14 Maharaj $v$ Maharaj supra n2 at 649 par I-J.

15 Marumoagae 2014 supra n2 at 2509. I agree with his submission. 
benefits during the course of the marriage which fell solely in his or her personal estate, such parties have only one joint estate and share in its profits and losses. ${ }^{16}$

The argument that the order is constitutive stems from a misunderstanding of the basic common law rules which govern a marriage in community of property, their consequences, and their legal ramifications. ${ }^{17}$ Community of property entails pooling of all assets and liabilities of the spouses immediately on and after marriage, automatically, by operation of the law. ${ }^{18}$ This means that immediately on the solemnization of a marriage, all assets, movable or immovable, corporeal or incorporeal brought by both spouses into the marriage become common by operation of the law, both as regards ownership and legal possession. ${ }^{19}$ No delivery, transfer or cession is required. ${ }^{20}$ Acquisitions by either spouse during the course of the marriage automatically fall into the joint estate. If the spouses are employed, their earnings form part of the joint estate. In our view, the pension interest forms part of the earnings of the spouses and is part of the joint estate. Consequently, both parties are each entitled to each other's pension interest by virtue of their marital regime. Accordingly, the insertion of the above-mentioned sections in the DA in 1989, did not create a new law. It only brought forward, to the divorce date the enjoyment/sharing of the pension interest. In other words, before the insertion of section 7(7)(a) the sharing of the retirement benefits was postponed to the resignation, retrenchment and/or retirement of the member; the accrual to the nonmember was delayed not denied. ${ }^{21}$

This was the law that existed before $1989^{22}$ and which still applies if one is married in community of property without accrual. Before 1989 an incorrect impression was created that the member's retirement benefits, did not form part of the joint estate because they were not shared on divorce. ${ }^{23}$ Accordingly, if on divorce a member spouse's retirement benefits did not form part of the joint estate, section 7(7)(a) of the DA was an enabling law for the non-member spouse. It was only after its insertion that the member spouse could access and share their

\section{Ibid.}

17 For a detailed discussion of the meaning of a marriage in community of property see Hahlo The South African Law of Husband and Wife (1975) 219; (1985) 157-158; Boberg's Law of Persons and Family (1999) 185; Heaton \& Kruger South African Family Law (2015) 61-82; Marumoagae 2016 Obiter 314. Also, Lamont's definition of community of property in $T v T 2014$ ZAGPJHC 245 par 15, where the husband tried to swindle the wife of her contributions to the joint estate by creating a trust.

18 Miltz AJ in D v D supra n12 at par 14.

19 See discussion in note 17 supra.

20 De Villiers CJ in Rosenberg $v$ Dry's Executors 1911 AD where the judge held that although the farm was registered in the name of the deceased husband, the ownership of one half-share was in the testatrix by virtue of their marital regime.

21 Marumoagae supra n2 at 2492, 2493; Mothupi supra n4 at 215.

22 The year ss 7(7)(a) and 7(8) of the DA came into effect.

23 Sempapalele $v$ Sempapalele supra $\mathrm{n} 1$ and cases that followed that decision. 
pension interest with the non-member spouse, which was impossible before $1989 .{ }^{24}$ Hence, the constitutive nature of the section according to some judges and writers. In our opinion, what the amendment sought to address was the conflict between the fundamental principles of a marriage in community of property and s 37A(1) of the Pension Funds Act, 1956 (PFA). Whereas the common law rules automatically entitled the non-member spouse to a half share of the member spouse's salary/ earnings/ savings or 'his estate' during the marriage and on divorce; $s$ $37 \mathrm{~A}(1)$ of the PFA forbade interference with a member's pension benefits before their retirement. It provided for the exceptional circumstances under which the benefits could be disturbed. ${ }^{25}$

The concept 'pension interest' did not exist before August $1989^{26}$ which meant that a divorced non-member spouse had to wait for the resignation, retirement or retrenchment of the member spouse in order to access their share of the pension benefit. ${ }^{27}$ The Divorce Amendment Act 7, 1989 sought to change the law as it was. Section 7(7)(a) deemed a member's pension interest an asset in his estate. Section 7(8) enabled the court to make an order to that effect. ${ }^{28}$ The 1989 amendment to the DA necessitated the amendment of related legislation, namely, The Pension Funds Act, 1956, The Income Tax Act, 1962 and The Maintenance Act, 1998. The Pension Funds Amendment Act 11, 2007 came into force on 13/09/2007.29 Section 28(e) of this amendment which sought to reinforce the amendment in the DA, provided that a benefit was deemed to accrue to the principal member on the date of divorce. Thus, a non-member spouse was enabled to claim their share of the member's pension interest. It was not clear among the legal practitioners and academics if the amendment applied to divorces that took place prior to September 2007. The Financial Services Laws General

$24 K v K$ supra n2 lower court judgment; Pienaar supra n2 at 39; Marumo 2014 2493 dealing with the history of the DA and s 37D of the Pension Fund Act of 1956.

25 Section 37A(1) of the PFA provides that "save to the extent permitted by this Act, the Income Tax Act 58, 1962, and the Maintenance Act, 1998 no benefit provided for in the rules of a registered fund ... or right to such benefit or right in respect of contributions made by or on behalf of a member, shall, notwithstanding anything to the contrary contained in the rules of such a fund, be capable of being reduced, transferred or otherwise ceded or of being pledged or hypothecated, or be able to be attached subjected to any form of execution under a judgment or order of court of law ..." Marumoagae Obiter 2016 316; Mothupi supra n4 at 214.

26 Marumoagae "Breaking up is hard to do, or is it? The clean-break principle explained" 2013 De Rebus 38; Nevondwe "The Law regarding the division of the retirement savings of a retirement fund member on his or her divorce with specific reference to Cockcroft v Mine Employees Pension Fund" 20073 BPLR 296 (PFA) 1

27 Levondwe supra n26 at 1; Marumoagae supra n2 at 2491-2.

28 Jeram "Is it still necessary to obtain a court order against a fund? A rebuttal" 2017 De Rebus 1. He discusses four reasons why it is still necessary to obtain a court order in terms of s 7(8) of the DA; Marumoagae 2014 2494; Marumoagae 201339.

29 Marumoagae supra n2 at 2493; Marumoagae 2013 supra n2 at 40. 
Amendment Act 22, 2008 came into effect on 01/11/2008. It amended section 37D by inserting s 37D(4)(d) which provides that any portion of the pension interest that is payable to a non-member spouse that was granted divorce prior to $13 / 09 / 2007$ is deemed to have accrued to the non-member spouse on 13/09/2007. The amendment applied only to retirement funds registered with the PFA. ${ }^{30}$ It was only in 2011 that the Government Employees Pension Law Amendment Act 19, 2011 introduced the clean break principle to the Government Employees' Pension Fund (the GEPF). ${ }^{31}$

The contention that, before 1989 , the retirement benefits did not form part of the joint estate lost sight of the fact that although the non-member spouse did not share in them on divorce, they did share them on the member spouse's retirement, resignation or retrenchment. ${ }^{32}$ The main hurdle was that there could be a very long period of time between the divorce and the retirement, resignation or retrenchment of the member spouse. Moreover, no interest accrued to the non-member's share of the retirement benefits from the divorce date to the actual payment on retirement, resignation or retrenchment of the member spouse. ${ }^{33}$ This was the problem which section 7(7)(a) sought to rectify. It brought the time of accrual of the pension interest for the non-member spouse forward to the day of divorce. 34

\section{$22 \quad$ Ndaba v Ndaba}

In Ndaba, the appellant and respondent were married in community of property in 2005. On the dissolution of their marriage in 2012, they signed a deed of settlement which was made an order of the court. They agreed to share their movable and immovable assets equally. In 2013, the appellant (wife) requested the respondent to start the process to divide the joint estate. When he seemed uninterested, she instituted motion proceedings in which she asked for an order for three things: the appointment of a liquidator, a declaratory order that she and the respondent were each entitled to $50 \%$ of each other's pension interest, and an instruction directing their respective pension funds to endorse their records accordingly. ${ }^{35}$ The respondent retorted that their respective pension interests did not form part of the joint estate; the applicant did not claim his pension interest on divorce and it did not form part of the settlement agreement. Finally, the respondent asserted, there was no order granted in terms of which the respondent's pension interest was

30 Marumoagae supra $\mathrm{n} 2$ at 2494.

31 Nevondwe supra n26 6; Marumoagae supra n2 at 2014 2495; Marumoagae 2013 supra $\mathrm{n} 2$ at 40.

32 Carrim Divorce benefits payable to a non-member under section 37D of the Pension Fund Act 24, 1956 (LLM dissertation 2013 UL) 9; Marumoagae 2014 supra $\mathrm{n} 2$ at 2493.

33 Carrim supra n32 9; Marumoagae 2014 supra n2 at 2492.

34 Ndaba v Ndaba supra n2 par 26; Carrim supra n32; Marumoagae 2014 n2 supra at 2493.

35 Ndaba $v$ Ndaba supra n2 par 3. 
deemed to be part of the assets of the joint estate. ${ }^{36}$ Put differently, the defence raised the following questions: Did the pension interest form part of the joint estate? Did the applicant have to plead and claim the pension interest? Did the pension interest form part of the settlement agreement? What were the implications of the absence of a section $7(7)$ (a) order? Marumoagae 37 added more questions pertinent to the meaning and interpretation of s 7(7)(a) of the DA which the SCA ought to have answered but failed to do so.

In the high court, Kgomo J dismissed the applicant's application on three grounds. First, he could not make an order declaring the parties' respective pension interests to be part of the joint estate so long after the dissolution of the marriage, especially given the court that granted the divorce failed to do so. ${ }^{38}$ Second, he could not supplement the blanket order of the division of the estate that had been made by the divorce court by including the parties' respective pension interests. Third, he concluded that section 7(7)(a) of the DA contemplates that an order should be made by the court granting the divorce decree. As a result, where the divorce court failed to make an order declaring the pension interest of the member spouse a part of the joint estate, it remained outside the joint estate. Finally, the parties' settlement agreement in the divorce court did not include their respective pension interests. ${ }^{39}$

Dissatisfied with the outcome, the appellant took the matter to the SCA. The main question for consideration by the SCA was whether a nonmember spouse in a marriage in community of property was entitled to the pension interest of the member spouse, in circumstances where the court granting the divorce did not make an order declaring such a pension interest to be an asset in the joint estate. Petse JA pointed out that the pension interest of the member spouse is by virtue of the parties' marriage in community of property, co-owned by both in equal shares; this is a common law principle. Consequently, the judge stated, section $7(7)(a)$ is an endorsement of this common law principle; it does not create a new marital principle, meaning that a pronouncement by the divorce court that the pension interest forms part of the joint estate is

$36 \quad$ Ndaba $v$ Ndaba supra $\mathrm{n} 2$ par 5.

37 Is the non-member spouse entitled to his/her spouse's pension interest? How does a non-member spouse derive an entitlement to her member spouse's pension interest? Does the pension interest fall automatically within the joint estate by operation of the law? Is the court competent to order the member spouse's retirement fund to pay over to the non-member spouse the percentage of his/her member spouse's pension interest on divorce when such was not pleaded and prayed for in the divorce papers? Are retirement funds justified in refusing to pay a percentage of the pension interest to a non-member spouse on the strength of the decree of divorce not citing or incorrectly citing the name of the funds? Should the nonmember be burdened with the obligation to approach a court for the variation of a divorce decree notwithstanding the fact that the relevant pension fund has confirmed that one of the parties to the divorce is its contributing member?

38 Ndaba $v$ Ndaba supra $\mathrm{n} 2$ par 6.

39 Ndaba $v$ Ndaba supra n2 par 6. 
declaratory $^{40}$ and not constitutive. In other words, the pension interest automatically forms part of the joint estate during the marriage and on divorce, and there is no change in its status.

Having concluded that a section 7(7)(a) order was declaratory and unnecessary, could the SCA make an order under section 7(8)? Is there any law which prohibits a court that did not hear the divorce, the SCA in this instance, from making a section 7(8) order? This question was aptly answered by Makgoka AJA in his dissenting judgment. He dissented on the ground that the settlement agreement of the parties which was made an order of the court, excluded the pension interest; the pension interest was neither a movable nor immovable asset. Furthermore, he pointed out, neither the high court nor the SCA had jurisdiction to make a section $7(8)$ order. Consequently, he concluded, it was only the court which granted the divorce that could order the pension fund to pay the nonmember a pension interest, in this instance, the regional court. Which meant that the appellant still had to make an application to the regional court for the section $7(8)$ order. ${ }^{41}$ He concluded that the pension fund to which both the parties belonged, the Government Employees' Pension Fund (GEPF), was empowered by law to give effect to an order made in terms of section 7(8)(a); the declaratory order made by the SCA was not very helpful to the appellant. ${ }^{42}$

Ndaba $v$ Ndaba answered some but not all the questions relating to the interpretation of sections $7(7)(\mathrm{a})$ and $7(8)$ of the DA. ${ }^{43}$ It limited its analysis of the facts and narrowed the ambit of what needed to be decided when it said that "... the real issue on appeal is therefore whether a non-member spouse in a marriage in community of property, is entitled to the pension interest of a member spouse in circumstances where the court granting the decree of divorce did not make an order declaring such pension interest to be part of the joint estate?" In so doing, it left some questions unanswered: Can a court grant an order relating to a pension interest despite the papers being silent on the issue? Should the non-member pray and plead for such an order?

The following section discusses various problems faced by a nonmember spouse in getting their share of the pension interest.

$40 \quad$ Ndaba $v$ Ndaba supra n2 par 25.

41 This point was successfully raised in Theron $v$ Sanlam Preservation Pension Fund Case No PFA/FS/19463/07/RM Pension Fund Adjudicator (PFA); Budhoo v Sasol Pension Fund PFA/GA/37937/2009/LPM; GEPF v Naidoo 2006 (6) 304 SCA.

42 The upshot of this is that unless and until one of the parties approaches the regional court for an order in terms of $s$ 7(8)(a) of the DA, the applicant's victory in this court would remain hollow and a brutum fulmen as far as the GEPF is concerned para 70.

43 Marumoagae supra n3 at 4. 


\section{Problems encountered by a non-member spouse in accessing their share of the pension interest}

In this section, I will highlight the current difficulties encountered by a non-member spouse in accessing their share of the pension interest. These include: protection of a member spouse's rights by the pension funds and pension administrators; failure of the member spouse to tell the non-member spouse that they belong to a particular retirement fund; resignation of the member spouse from employment during divorce proceedings; multiplicity of court processes and attendant costs; rejection of divorce orders and/or settlement agreements by pension funds; uncertainty on what percentage of the pension interest the nonmember spouse is entitled to on divorce; and taxation of the pension interest payout to a non-member spouse.

\section{Protection of member spouse's rights by retirement funds/administrators}

Retirement funds and administrators are very reluctant to divulge any information regarding the pension interest of the member spouse to the non-member spouse. This could be because most fund rules include confidentiality clauses for the protection of the member spouse's right to privacy. ${ }^{44}$ A case in point is $B L v F L^{45}$ where the court order granted the applicant a $50 \%$ share of the first respondent's pension interest in the Transnet Retirement Fund. When the first respondent's pension interest accrued, he transferred R156 634.79 to the trust account of the applicant's attorney plus R5 090.18 for her legal costs.

Dissatisfied with the small amount received, the applicant sought a mandatory order against the first and second respondents respectively, compelling them to provide the value of the first respondent's pension interest. She also asked for a true and proper statement together with substantiating documents (par 2.1) reflecting the value of the benefits paid to the first respondent in the Transnet Retirement Fund (par 2.2). The first respondent's defence that the application was ill-conceived and that the name of the fund was incorrect was thrown out of court. It found that the applicant was entitled to the information she was asking for and ordered the first respondent to supply it.

I submit that where the member spouse is acting fraudulently and to the detriment of the non-member spouse, the pension fund/ administrator should voluntarily/readily give the correct information to the attorneys of the non-member spouse. In this way, unnecessary court processes can be avoided. In this case, the first and second respondents'

44 Carrim supra n32 32.

45 BL $v$ FL 20154 SA 271. 
attorneys acted in bad faith and should have been made to bear the brunt of their unprofessional actions.

In Smith $v$ Smith $^{46}$ the court had allocated a portion of the member's pension interest to the non-member on divorce. The latter requested information pertaining to the pension interest from the fund which refused on the ground of the member's right to privacy. The court ordered the fund to supply the requested information and observed that, in fulfilling their duty of good faith, funds are obliged to disclose to the non-members and beneficiaries such information as is reasonable for the exercise and protection of any right. ${ }^{47}$ The failure or refusal to do so without appropriate justification would amount to the improper exercise of the fund's powers. The court concluded that the non-member spouse had a right to access information relevant to the amount due to them, including how the amount was calculated and the terms and conditions governing payment of the benefits. ${ }^{48}$

\section{Failure of member spouse to tell non-member spouse that they belong to a retirement fund, and failure to disclose its name}

Sometimes, a member spouse inadvertently or deliberately fails to inform a non-member spouse that s/he belongs to a retirement fund and/ or the name of the fund. As a result, the latter will, on divorce, not claim their share of the pension interest. A non-member spouse's right to share in the member's pension interest will be adversely affected by lack of knowledge of such crucial information. Fritz's ${ }^{49}$ case demonstrates the repercussions of the failure of the member spouse to disclose to the nonmember spouse that they belong to a pension fund and failure to disclose its name. The deceased member spouse belonged to a pension fund during their marriage and on divorce. The non-member spouse, the wife, did not know about this and consequently did not claim her share of the pension interest on divorce. After divorce, the deceased transferred his pension interest to the first respondent, the transferee fund. When the wife claimed her share of the pension interest, the transferee fund's defence was that the deceased transferred his pension interest to the first respondent after divorce and was not a member on divorce. The point the wife was making was that on divorce, her husband belonged to the transferor pension fund. She was claiming a percentage of the pension interest before it was transferred because her entitlement was not deducted. ${ }^{50}$

46 S2004 2 BPLR 5431 (SCA). This case is discussed by Carrim supra n32 32.

47 Carrim supra n32 32; Nevondwe supra n26 5.

48 Carrim supra n32 32.

49 Fritz v Fundsatwork Umbrella Pension Fund 20134 SA 492 (EC) 493; Kv K discussed by Davey J, demonstrates the same point. The wife did not claim her share of the pension interest on divorce because she did not know that her husband belonged to a pension fund (he failed to tell her) supra n2.

Fritz $v$ Fundsatwork supra $\mathrm{n} 49$ at par $\mathrm{H}-\mathrm{J}$. 


\section{Resignation of a member spouse from employment during divorce proceedings}

The right of the non-member spouse to share equitably in the member spouse's pension interest will be adversely affected by the resignation of the member spouse from employment during divorce proceedings. ${ }^{51}$ According to section 1 of the DA the pension interest means the benefits to which a member of a fund would have been entitled to in terms of the rules of the fund, had his/her membership terminated on the date of divorce on account of their resignation from office. ${ }^{52}$ According to some courts, ${ }^{53}$ implicit in this definition, is the fact that the member must be a member of the fund on divorce, failing which there is no pension interest to talk about. ${ }^{54}$ In other words, in order to calculate the pension interest, the member spouse has to be in active employment and active fund membership at the date of divorce so that it may be deemed that s/he has resigned. 55

In Elesang ${ }^{56}$ the member spouse resigned from work after the issue of divorce summonses and he became entitled to his pension interest withdrawal benefit. Apprehensive that the member spouse was going to prejudice her share in the pension benefit, the applicant (wife) asked for a provisional order requesting the second respondent, the provident fund, to pay half of the member spouse's pension interest into the trust account of her attorney. The provident fund opposed the application on the ground that as the member resigned from his employment when summonses were issued, he would not be a member of the fund on divorce, which meant that the court granting the divorce would be unable to make a divorce order contemplated in section $7(7)(\mathrm{a})$ of the DA. According to the fund, the enabling section could only be invoked if the member spouse was still a member of the fund on divorce. The court observed that the member's pension benefit formed part of the joint estate and that the applicant's apprehension was reasonable and it found in her favour. This demonstrates how a member spouse with the assistance of his fund tried unsuccessfully to frustrate the rights of the non-member spouse in sharing the pension interest.

51 Marumoagae supra n2 at 2512.

52 Pension interest, in relation to a party to a divorce action who - (a) is a member of a pension fund ... means the benefits to which that party as such a member would have been entitled in terms of the rules of that fund if his membership of the fund would have terminated on the date of the divorce on account of his resignation from office; Marumoagae 20142496.

53 Elesang $v$ PPC Lime Ltd 20076 SA 328 (NCPV); Marumoagae supra n2.

54 Marumoagae 2014 supra n2 at 2511-13; Marumoagae 2016320.

55 Marumoagae 2014 supra $\mathrm{n} 2$ at 2511-13; Splitting a pension on divorce IOL 5.

56 Elesang $v$ PPC Lime Ltd supra n53. 
In Naidoo ${ }^{57}$ a divorce order determined that the non-member spouse, Mrs Naidoo, was entitled to $50 \%$ of the member's pension interest, calculated on the day of divorce but payable when the benefits accrued to the defendant husband. The manager of the fund was instructed to endorse the records accordingly. However, he instead wrote to Mrs Naidoo's attorney telling him that the fund would pay Mrs Naidoo provided that Mr Naidoo was still employed on the day of divorce. As $\mathrm{Mr}$ Naidoo had resigned prior to the divorce date, Mrs Naidoo applied ex parte for an order: directing $\mathrm{Mr}$ Naidoo to facilitate administrative requirements for fund payment; restraining Mr Naidoo from getting her half share in the fund; interdicting the fund from paying her half share to Mr Naidoo; and directing the fund to pay her pension interest to her attorneys. The fund retorted that it was prohibited by section 21(1) of the Government Employees' Pension Law, $1996^{58}$ from paying Mrs Naidoo. Jappie J disagreed with the fund and held that Mrs Naidoo was not a creditor but was claiming her half share of the joint estate to which she was entitled by operation of the law. On appeal to the SCA, the judges agreed with the lower court and dismissed the appeal.

\section{Multiplicity of court processes ${ }^{59}$}

Litigation is emotionally, physically and financially taxing for litigants generally and for a divorcing couple in particular. More so, because a divorce order is just the beginning of a litany of court processes to follow. ${ }^{60}$ De Jong laments the postponement of the adjudication of the actual division of the joint estate to be finalized by a liquidator because it results in the piecemeal adjudication of issues that originate from one and the same divorce matter. These are the actual division of the assets, maintenance of the wife and the children, if any, and the sharing of the pension interest. A non-member spouse might have to go through a

57 GEPF $v$ Naidoo 20066304 SCA. In Maharaj the member spouse had resigned from work and was about to be paid his pension. The applicant successfully interdicted the GEPF from paying her husband the sum of R19 788.84 , her notional half share of the pension interest on divorce, pending the division of the joint estate.

58 The section provides "Subject to section 24A, no benefit or right in respect of a benefit payable under this Act shall be capable of being assigned or transferred or otherwise ceded or of being pledged or hypothecated or, save as is provided in ... section 7(8) of the Divorce Act, 1979, be liable to be attached or subjected to any form of execution under a judgment or order of a court of law."

59 Ndaba $v$ Ndaba went through four court processes: in 2012 the divorce proceedings, 2013 the motion proceedings which were dismissed by Kgomo J, 2015 the SCA application where the appellant got her $50 \%$ share of the respondent's pension interest and the fourth court process back to a regional court in terms of $\mathrm{s} 7(8)$.

60 De Jong "The need for new legislation and/or divorce mediation to counter some commonly experienced problems with the division of assets upon divorce” 2012 Stell LR 228. 
number of court processes before getting their share of the pension interest; they bear the brunt of this endless adjudication. ${ }^{61}$

For instance, Eskom Pension and Provident Fund $v$ Krugel $^{62}$ went through four court processes. In 2001 the parties divorced and agreed in a deed of settlement that the wife would get $25 \%$ of the husband's pension interest. The fund refused to endorse its records accordingly, because, at the time of divorce, the husband had elected to be a deferred member and no longer had a pension interest in the fund as contemplated in section 7(7)(a) of the DA, read with section 37D of the Pension Fund Act. The second process was lodged by the non-member spouse to the Pension Funds' Adjudicator, in terms of section 30A of the Pension Funds Act. The adjudicator found in the non-member's favour, based on section 37D(6) and 37D(4) of the PFA. The adjudicator was of the view that section $37 \mathrm{D}(4)(\mathrm{d})$ included deferred or preserved benefits which were to be regarded as a pension interest to be shared on divorce, and thus determined that Krugel's deferment of his benefit until he was 55 years old did not prevent the non-member spouse from getting her share on divorce. The adjudicator concluded that the benefit was deemed, in terms of section 37D(4)(a), to have accrued to Krugel (par 4). The fund disagreed with the determination of the PFA and took it on review to the South Gauteng High Court (SGHC). Lamont J dismissed the application on the grounds that Mr Krugel was a member of the pension fund on divorce and owned an asset, the pension interest, which he had to share with his wife (par 5). The fourth process was an appeal to the high court by the fund. The main ground of appeal was that the member had resigned from the fund on divorce and the orders in terms of sections 7(7)(a) and 7(8) were unenforceable (par 6). The high court upheld the appeal, but agreed that the wife could still claim her money when Krugel reached 55 years of age as agreed in the deed of settlement.

\section{Rejection of divorce orders and/or settlement agreements by retirement funds}

John Anderson has cautioned that $28 \%$ of divorce settlements served on funds administered by Alexander Forbes, the largest administrator of retirement funds in South Africa, are rejected, and that the proportion of unenforceable divorce orders has increased from $8 \%$ to $24 \% .{ }^{63}$ According to Anderson, both the non-member and member spouse must ask the administrator of the fund before divorce what the current fund value is, and also the present value of the pension interest. He warned

61 Mothupi observed that the requirement of naming the fund in the order might be costly and time consuming for the non-member spouse to meet. The non-member spouse had to request an amendment of the divorce order that did not clearly name the fund. The complainant would have to hire attorneys to have the divorce order rectified, and must file a new complaint clearly stating the name of the fund involved supra n4 215-6.

$62 \quad \mathrm{~N} 7$

63 Cameron "Splitting a pension on divorce" www.iol.co.za/business/personalfinance/retirement/splitting-a-pension-on-divorce-1218453 1. 
that the correct name of the fund must be used at all times failing which the divorce order/settlement agreement will be unenforceable. ${ }^{64} \mathrm{~A}$ portion of the pension interest must be stipulated in the order and the fund must be ordered to make payment of the portion awarded to the non-member spouse, and endorse its records. Where a member belongs to more than one pension fund, the divorce order must specify the pension fund the pension interest is supposed to come from otherwise, it will not be enforceable. Echoing Anderson, a pension fund administrator stressed that fund administrators stick to the letter of the law when processing such pay-outs, to avoid any liability. ${ }^{65}$ According to them, the divorce order must specify the percentage of the pension interest assigned to the non-member spouse. Also, the pension fund must be identified by name in the order; referral to a member's 'retirement fund' will not suffice. ${ }^{66}$

Sayster $v$ SABC Pension Fund ${ }^{67}$ illustrates some of the concerns raised by Anderson above. The complainant was a former spouse of Mr Sayster who was a member of the SABC pension fund, administered by the second respondent. On divorce the parties signed a settlement agreement which was made an order of the court. ${ }^{68}$ When presented with the divorce order, the fund refused to pay the defendant's wife on the ground that the order did not comply with the provisions of the DA and was therefore unenforceable; the wife was advised to amend the order and re-submit it to the fund. She enlisted the services of an attorney and sought assistance from the second respondent, the administrators, who advised the attorney accordingly. The amended order was, according to the second respondent, still unenforceable for the following reasons: First, the order failed to name the fund; it purported to award a portion of something other than the 'pension interest'. The amended decree stipulated that "the pension interest shall be calculated from date of marriage until date of divorce" (par 4.3) which conflicted with the DA.

64 Jeram supra n28 at 2;

65 10X Investments "Divorce and your retirement fund" www.10x.co.za/blog/ divorce-and-your-retirement-fund/

66 Mothupi pointed out that the defences raised by the funds and the administrators were technical and were based on the actual wording of the divorce order. This approach he concluded, prejudiced the non-member spouse and their right to share in the pension interest supra n4 at 215-216, 219-220; Jeram supra n28 1; "Divorce and retirement funds in South Africa - A guide to family law" www.divorcelaws.co.za/divorce-and-retirementfunds-in-south-africa.html 1 .

67 [2016] 3 BPLR 446 (PFA).

68 The settlement agreement read: "The Plaintiff is a member of the SABC Pension Fund, persal number 013230, whereby he has acquired a pension interest as described in Act 70 of 1979 , as amended. It is agreed that the Defendant is entitled to $50 \%$ of the said pension interest of the Plaintiff, calculated from date of marriage to date of divorce, being 17 January 2014. The parties herein agree and confirm that an order be made, that by producing the final divorce order made by this Honourable Court, the Administrator of the SABC Provident Fund, is ordered to endorse their records accordingly ...." 
Dissatisfied with the decision of the first respondent, the defendant sought assistance from the PFA.

In response to the PFA's questions, the first respondent elaborated on the reasons for declining to pay the defendant after the order had been amended: the first respondent observed that the order directed the administrators of the fund to pay, not the fund; it purported to change the definition of the pension interest in the DA; the amended order did not refer to the original order that was being amended, and how it was amended; there was no section 7(8) order asking the fund to endorse its records accordingly; and the fund concluded it would be contravening the law if it paid the complainant without a valid order. The Tribunal agreed with the first respondent's submissions and dismissed the complaint.

\section{Taxation of pension interest payout to the non- member spouse}

There are tax implications for the deduction of the pension interest. Section 37D(i)(d)(ii) of the Pension Fund Act provides for the deduction of tax on any pension interest paid to a non-member spouse, in terms of a divorce order contemplated in section 7(7)(a) of the DA. ${ }^{69}$ Taxation of allocated pension interest is, however, exceptionally complex. ${ }^{70}$ Before 2007, the tax deduction was, in terms of a provision in the Income Tax Act, that when a non-member spouse's portion accrued, the member spouse was liable to pay the income tax. ${ }^{71}$ The member could recover the tax from the non-member spouse. The 2007 amendment provides that divorce orders granted after 13 September 2007 will hold the member liable for tax on the withdrawal amount at his or her average rate. However, where a court order is granted after 13 September 2007 , the non-member spouse will be held liable for the tax if the election takes place after 1 March 2009. The non-member was liable to pay the tax in divorces that occurred after 1 March 2009, even if the divorce order was granted before 1 March 2009 but after 13 September 2007.72 If the whole pension interest was transferred to another retirement fund, the transfer was cost free. Currently, any allocation of a pension interest deducted by a fund will be taxed in the hands of the non-member spouse. $^{73}$

In $N R v E R^{74}$ the parties were divorced in 2006. They agreed on a deed of settlement which was made an order of the court. Clause 5 gave the wife (first respondent) $30 \%$ of her former husband's pension interest. In terms of the amendment of section 37D(4)(b)(i) of the PFA she became

69 Carrim supra n32 at 14-22.

70 MacKenzie supra n49 at 11.

71 Freund "Splitting pension on divorce" IOL 12.

72 Sigodi A law regulating taxation of pension benefits in South Africa (LLM dissertation 2015 LU) 19; Carrim supra n32 14.

73 Mackenzie supra n49 11.

7420122 SA 481. 
entitled to exercise an election for the payment of her $30 \%$ interest, at any time before the member's retirement and/or resignation. The lump sum payment was taxed. The husband sought an order against his wife for the payment of the amount of R135 614.27 in respect of the tax deducted from his pension interest in the fund. The wife contended that the $30 \%$ assigned to her in clause 5 was the total due and payable to her without any tax deduction. She contended that according to the settlement agreement, he had no right of recovery against her. Furthermore, she retorted, the tax was charged to the lump sum paid to the member and not her $30 \%$ share. The court disagreed with her contention and held that the husband's right to recover the tax liability paid was not based on the deed of settlement but on the law. The court held that the wife's $30 \%$ was taxed in the hands of the member who had the right to recover the tax paid from the non-member.

\section{What percentage of the pension interest is the non- member spouse entitled to on divorce?}

According to section 7(8)(a)(i) of the DA, the court granting a decree of divorce in respect of a member of a fund may make an order assigning any part of the pension interest to a non-member spouse. ${ }^{75}$ Once a divorce order is forwarded to a retirement fund, the latter must deduct the amount in question from the member's pension interest and pay it to the non-member. The divorce order must specify the percentage to be allocated. In my view this requirement is misplaced. A judge cannot determine the percentage that the non-member is entitled to when the value of the pension interest of the member spouse is unknown. At the proceedings stage, it is doubtful if the member knows how much his/her pension interest is worth, because the pension fund has not been mandated by the court to calculate it. Though it is possible to compel a pension fund to provide the non-member spouse with the breakdown of their entitlement on divorce, the pension fund is not usually joined in the proceedings.

Some judgments determine the percentage of the pension interest to be awarded to the non-member spouse as ranging from $25 \%$ to $100 \%, 76$ while others do not. However, if according to Ndaba the non-member spouse's entitlement is based on the parties' type of marriage, and the

75 Sigodi supra $\mathrm{n} 72$ at 17; Cameron supra $\mathrm{n} 43$ at 4 . This section raises more questions than answers. For instance, how does a judge determine the percentage to be awarded to the non-member spouse? At this stage of the proceedings the member spouse's entitlement has not been calculated. It is only calculated by the fund after receiving a divorce order in terms of $\mathrm{s}$ 7(7)(a) of the DA.

76 D v D $25 \%$; NR v ER $30 \%$; Chiloane $50 \%$; RN v FK $50 \%$; Peters $50 \%$; GEPF v Naidoo $50 \%$; Elesang $50 \%$; BL v FL $50 \%$; Sayster $50 \%$; Ndaba $50 \%$; D de Kwaadsteniet $v$ Lifestyle Retirement Annuity Fund Group Limited Unreported case no 2 of 2010 (PFA) $100 \%$. Unfortunately, these judgments are all on appeal, and consequently there is no discussion of the rationale or reasons for the percentages awarded. 
pension interest forms part of the joint estate, the non-member spouse must get $50 \%$ of the pension interest after tax and other legally permissible deductions. There is no justification for them to get less.

In $D \vee D^{77}$ the defendant wife was awarded $25 \%$ of her former husband's pension interest instead of $50 \%$. The court penalised her because she had, on resignation from her job, not shared her pension interest with her former husband. Instead, she gave it to her parents. However, I disagree with the $25 \%$ award. The defendant had worked for only 6 months when she resigned to join the plaintiff in New York. Although the position she held is not specified, it is obvious that a pension interest for 6 months' employment minus tax, is a far cry from her husband's pension interest. He held a good position as an SABC TV journalist and had, on their divorce, worked for 10 years. The court should have compensated this glaring discrepancy.

Sempapalele ${ }^{78}$ and Maharaj ${ }^{79}$ illustrate this point. In the former case, the applicant's claim for R263 162.47 as her half share of the pension interest failed because she did not know the actual value of the respondent's pension interest. Her claim was dismissed because it was unsubstantiated. Mrs Maharaj also did not know the value of her husband's pension interest but was assisted by the Government Employees Pension Fund which advised her that she was entitled to R19 788.84. The GEPF was interdicted and restrained from paying to the bank the sum of money in question. Her application was successful in that her share of the pension fund was secured, pending the division of the joint estate.

\section{Conclusion}

The article discusses the controversy caused by divergent interpretations of sections $7(7)(\mathrm{a})$ and $7(8)$ of the DA. It Indicates that some courts conflate the common law principles of a marriage in community of property with the provisions of section 7(7)(a). It discusses the SCA decision in Ndaba $v$ Ndaba which failed to answer some questions raised by the interpretation of the sections. It highlights some hurdles encountered by a non-member spouse in accessing their share of the pension interest.

77 See sources listed in n10 supra.

78 Sempapalele $v$ Sempapalele 20012 SA 306.

79 See sources listed in $\mathrm{n} 2$ supra. 